\title{
Effect of Rosemary and Oregano Extracts Incorporated Chitosan Films on the Quality and Shelf Life of Indian Mackerel (Rastrelliger kanagurta) Steaks during Ice Storage
}

\author{
M. Kumuda ${ }^{1}$, K. Dhanapal ${ }^{1 *}$, K. Sravani ${ }^{1}$, K. Madhavi ${ }^{2}$ and G. Praveen Kumar ${ }^{1}$ \\ ${ }^{1}$ Department of Fish Processing Technology, ${ }^{2}$ Department of Aquatic Environment \\ Management, College of Fishery Science, Muthukur, Nellore District, Andhra Pradesh, India \\ *Corresponding author
}

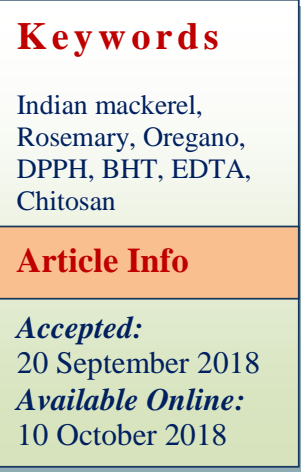

\section{Introduction}

Indian mackerel (Rastrelliger kanagurta) a pelagic species belonging to the family Scombridae is found naturally and very abundantly in the east and west coast of India.

\section{A B S T R A C T}

The effect of rosemary extract and oregano extract was compared with Butylated Hydroxytoluene (BHT) which was incorporated in chitosan film and studied the quality and shelflife of Indian Mackerel (Rastrelliger kanagurta) steaks during ice storage. The quality of the product was analysed by using biochemical methods (peroxide value, free fatty acid, thiobarbituric acid, trimethyl amino nitrogen, total volatile basic nitrogen, $\mathrm{pH}$ ), microbial methods (total plate count) and sensory quality. The antioxidant properties of rosemary and oregano extracts were tested in vitro at varied concentrations (100 to 500 ppm) and growth inhibition was seen against gram positive and gram negative bacteria by disc diffusion method. It was observed that 2,2-diphenyl-1-picrylhydrazyl (DPPH) scavenging activity of Rosemary and Oregano extracts at 100ppm concentration were $77.37 \%$ and $62.86 \%$ respectively. Rosemary extract showed highest ferric reducing activity at all concentrations $(100-500 \mathrm{ppm})$ and exhibited highest reducing power at $500 \mu \mathrm{g}$ $/ \mathrm{mL}$, almost equivalent to BHT at $200 \mathrm{mg} / \mathrm{L}$. Rosemary extract exhibited more chelating activity compared to oregano extract, although both extracts were less efficient compared to synthetic metal chelator, Ethylene diamine tetraacetic acid (EDTA). Rosemary and Oregano extracts were potentially active against gram+ve bacteria whereas, it showed smaller zones of inhibition against gram-ve bacteria. The effect of $1 \%$ chitosan, $1 \%$ chitosan with 200ppm of BHT, $1 \%$ chitosan with 500ppm of rosemary and $1 \%$ chitosan with $500 \mathrm{ppm}$ of oregano treatments on quality changes of Indian mackerel steaks during ice storage for 21 days were investigated. 
products. Commercial use of Indian mackerel has been limited by the susceptibility of the fish to oxidative reaction of its lipids. Apart from lipid oxidation, the quality loss of the Indian mackerel was due to microbial spoilage, which is prime contributor for its spoilage. Oxidation can also cause other detrimental effects such as discoloration, vitamin destruction and decomposition of essential fatty acids, leading to organoleptic failure and a decrease in nutritive value (Sherwin, 1978). To retard such a quality loss, synthetic antioxidants and antimicrobials have been used to decrease lipid oxidation and microbial spoilage during the processing and storage of fish and fishery products (Boyd et al., 1993).

Therefore, enhancing shelf life of seafood with natural preservatives and edible film is an important issue to eliminate economic losses and provide safe and good quality food to consumer and reach to distant markets (Kykkidou et al., 2009). Edible films and coatings are used in a variety of applications in the food industry. The use of edible coating has a beneficial effect on the preservation of sea food products, since they act as barrier against moisture and oxygen penetration (Pereira et al., 2010).

Chitosan and chitosan based materials can be used as edible films and coating. Chitosan is produced commercially by deacetylation of chitin (Mathur and Narang, 1990). It is a linear polysaccharide composed of randomly distributed $\beta$-(1-4)-linked D-glucosamine (deacetylated unit) and N-acetyl-Dglucosamine (acetylated unit). Chitosan, a.cationic polysaccharide mainly made from crustacean shells, is a well-known film forming biopolymer with strong antimicrobial $\&$ antifungal activities (Aider, 2010; Duan et al., 2010). The antimicrobial activity of chitosan film is due to positively charged chitosan molecule act on negatively charged microbial cell membrane. The antioxidant activity of chitosan is to inhibit the reactive oxygen species present in lipid oxidation of food and biological systems. Chitosan can scavenge free radicals or chelate metal ions from the donation of hydrogen or the alone pairs of electron (Xie, 2001; Liu et al., 2009; Onsosyen and Skaugrud, 1990). The current increase in consumer demand for synthetic antioxidants replace by the use of natural antioxidants and antimicrobial compounds has forced companies and researchers to explore different ways to improve their market penetration by offering products with improvements in quality, freshness and food safety. One of the more fashionable trends consists of the development of innovative biopolymers obtained from agricultural commodities and/ or food-waste products.

Plant extract of Rosemary (Rosemarinus officinalis) is one of the most effective spices widely used in food processing. It is the most important spices commercially available for use as an antioxidant and antimicrobial substance. The first use of an extract of rosemary leaves as an antioxidant was reported by Rac and Ostric (1955). The application of rosemary extracts in food had given a variety of results and these depend on the test model being used. Rosemary was considered as a lipid antioxidant, metal chelator and found to scavenge superoxide radicals. The capability of rosemary extracts in retarding lipid oxidation of different fish oils was reported by Bhale et al., (2007). Oregano (Origanum vulgare) was very often used as a spices and its flavour is very popular with consumers all over the world. Oregano phenolics have significant antioxidant activity and are effective in the inhibition of all phases of the peroxidative processes by neutralizing free radicals, blocking the oxidation catalysis by iron and interrupting the lipid radical chain reactions (Dornan et al., 2003). Primarily rosmarinic acid is the major phenolic 
component of oregano extract, which can prevent colour deterioration (Hernandez et al., 2009). The dried oregano has demonstrated in vitro antibacterial activity against a wide range of gram+ve and gram-ve microorganisms.

\section{Materials and Methods}

\section{Materials}

\section{Preparation of chitosan film}

The chitosan film was prepared by the casting method (Kanatt et al., 2012). The known concentration of chitosan powder was taken and dissolved in $100 \mathrm{ml}$ of $1 \%$ acetic acid solution. The chitosan and acetic acid solution were stirred continuously for 30 min's with the help of magnetic stirrer and $1 \mathrm{~mL}$ glycerol (film forming solution) was added as the plasticizer in the solution and again stirred for 15 min's. After filtration, known volume (25$30 \mathrm{ml}$ each plate) of the solution was poured into the petri plates. These petri plates were dried at $65-70^{\circ} \mathrm{C}$ in hot air oven. After drying, immediately they were cooled to room temperature. Then $5 \mathrm{ml}$ of $1 \mathrm{M} \mathrm{NaOH}$ (sodium hydroxide) solution was added on the surface of dried film as it helps for easy peeling of film. Once the films were peeled, they were washed thoroughly in water, dried and used for further studies.

\section{Standardization of chitosan for dip treatment}

Preliminary experiments were conducted to standardize the various levels of Chitosan required for the preparation of the film and incorporated with mackerel steaks and to optimize processing conditions. Different concentrations about $0.25 \%, 0.5 \%, 0.75 \%$ and $1.0 \%$ of chiotsan film were prepared and to analyze the size and thickness. Among these concentration $1 \%$ level is give better thickness and size compared to the $2 \%$ (it give more thickness). Based on the analysis in order to find out a right standard level for the preparation of chitosan film selected and were used for storage studies.

\section{Comparison between the chitosan and control}

Before going to conduct the dip treatment in preliminary test between the chitosan treated sample and control sample. Both the samples were analyzing quality parameters including the biochemical, microbial and sensory characteristics shown in Table 1 and 2.

Based on the quality parameter analysis chitosan treated sample showed better quality compared to the control groups. So that the chitosan treated sample were kept as the control for present study.

\section{Dip treatment}

Indian Mackerel steaks were randomly assigned into four groups. Among these the first group steaks were coated with chitosan only (control). The second, third and fourth groups were treated with chitosan solution incorporated with 200ppm of BHT, 500ppm of Rosemary and 500ppm of Oregano respectively. The time for the dip treatment process for all the treatments is 10 min's.

\section{Sampling}

During ice storage studies of mackerel steaks samples were drawn randomly at an interval of every 3 days, up to 21 days in order to evaluate the lipid oxidation, microbiological, biochemical parameters and sensory parameter.

\section{Plant varieties}

Two varieties of plants viz., Rosemary and Oregano were used for the study. 


\section{Glassware and packing material}

All glassware's were procured from Merck, Borosil, Qualigen laboratories, India. 500g capacity High Density Polyethylene (HDPE) pouches (400 gauge) of size $24 \times 17.8 \mathrm{~cm}$ were used for packaging of mackerel steaks.

\section{Chemical and microbiological media}

All the chemicals and reagents used in the present study were obtained from Merck (Mumbai), SD-fine chemicals (Mumbai) and Loba (Mumbai) were of analytical grade (AR) or guaranteed grade (GR). The glassware manufactured by Borosil, Technico, and Schott Duran was used during the study. The media used for microbiological studies were manufactured by Hi-Media (Mumbai). Chitosan powder was purchased from Nano Wings Pvt. Ltd., Khammam.

\section{Bacterial cultures}

Bacterial cultures, namely Staphylococcus aureus (NCIM 2079), Escherichia coli (NCIM 2688), Bacillus subtilis (NCIM 2063), Salmonella typhium (NCIM 2501) and Pseudomonas fluorescens (NCIM 2099) were brought from the Department of Fish Processing Technology, College of Fisheries, Mangalore, India. The above cultures were grown in nutrient agar media (Hi Media, Mumbai, India) at $37^{\circ} \mathrm{C}$. Each bacterial strain was transferred from slants stored at $4-5^{\circ} \mathrm{C}$ to $10 \mathrm{ml}$ nutrient broth and cultivated at $37^{\circ} \mathrm{C}$ for $24 \mathrm{~h}$. Pre culture was prepared by transferring $1 \mathrm{ml}$ of this culture to $9 \mathrm{ml}$ nutrient broth and cultivated for $48 \mathrm{~h}$.

\section{Methods}

\section{Antioxidant capacity (AOC) of Rosemary and Oregano}

The DPPH radical scavenging activity of rosemary and oregano at various concentrations was determined according to the method as described by Yen and $\mathrm{Wu}$ (1999). The ferric reducing antioxidant power of rosemary and oregano was measured to reduce ferric ions to ferrous ions as determined at different concentrations by the method of Oyaizu (1986). The chelating activity of rosemary and oregano at different concentration was measured by the method of Boyer and Mccleary (1987) and was compared with standard metal chelator EDTA at $1 \mathrm{mM}$.

Antimicrobial activity of Rosemary and Oregano by disc diffusion method

The antibacterial test for rosemary and oregano were performed by the agar disc diffusion method (Bauer et al., 1966; Nair and Chanda, 2005).

\section{Chemical analysis}

Peroxide value was determined according to Jacobs (1958). TBA value was determined as described by Tarladgis et al., (1960), Color developed was measured using a UV-VIS spectrophotometer (M/s. UNICO spectrophotometer, USA) at $538 \mathrm{~nm}$ and expressed as mg malonaldehyde (MA) per $\mathrm{kg}$ of sample. Total Volatile Base Nitrogen (TVB-N) and Trimethyl amine Nitrogen TMA-N was determined by the method of Conway (1962) and expressed as $\mathrm{mg} / 100 \mathrm{~g}$ of sample. $\mathrm{pH}$ value was determined according to APHA(1998) using a digital $\mathrm{pH}$ meter (M/s. Oakton, Eutech instruments, Malaysia) after homogenizing $5 \mathrm{~g}$ of the fish sample with the $50 \mathrm{ml}$ of distilled water. Free fatty acid was (FFA) content in the lipid extract was determined by Olley and Lovern (1960) method.

\section{Bacteriological analysis}

All the microbial analysis was enumerated as per the procedures described in APHA (1992). The microbial count was estimated by spread 
plate technique. $25 \mathrm{~g}$ of the sample was weighed aseptically and diluted with $225 \mathrm{ml}$ of physiological saline solution. Samples were homogenized using stomacher (M/s. Lab-Med, England) and prepared serial dilutions at all possible aseptic precautions. Using the sterile pipette, $1 \mathrm{ml}$ of the supernatant was aseptically transferred into $9 \mathrm{ml}$ of saline tube and mixed well using vortex mixer. Similarly, further decimal dilutions were prepared using physiological saline $(0.85 \%$ sodium chloride solution).

\section{Sensory analysis}

Sensory characteristics of the fish steaks were evaluated by selected panel members who have experience in evaluation of similar products, on a ten-point scale (Indian Standard, 1971; Vijayan, 1984). Scores were assigned to ' 1 ' being the least and ' 10 ' being the highest for attributes as described by Vijayan (1984). The characteristics covered under the taste panel were appearance, color, flavor, taste, texture and overall acceptability for chitosan coating mackerel steaks treated with Rosemary and Oregano. Score 10excellent to1-very dislike respectively for each of the sensory characteristics.

\section{Statistical analysis}

The Statistical Package for Social Sciences [SPSS 20 and IBM 2010] was used for analysis of the experimental results. The results were expressed as mean \pm Standard Deviation (SD). Sufficient number of samples was carried out for each analysis.

\section{Results and Discussion}

\section{Antioxidant activity of rosemary and oregano}

The antioxidant potential of plant products and pure compounds was evaluated using numerous assays. The first step in these examinations is the screening of the potential activity by different in vitro tests. Each of those is based on one feature of the antioxidant activity, such as the ability of scavenging free radicals, the ferric reducing power assay, the chelating of metal ions. However, in order to get relevant data, a single method for testing antioxidant activities of plant products is not recommended due to their complex composition (Nuutila et al., 2003). Therefore, the antioxidant activity of the tested rosemary and oregano has been evaluated in a series of in vitro tests.

\section{DPPH radical scavenging activity rosemary and oregano}

The DPPH radical scavenging activity of rosemary and oregano were shown in Table.3. The radical scavenging activity of the both the extracts were seen at different concentrations and with the increase in concentration, the radical scavenging activities of both the extracts decreased. At the same concentration used, the descending orders of DPPH radical scavenging activity of the tested compounds was as follows: Rosemary > Oregano.

The present results agreed with the findings of Hendel et al., (2016) who reported that rosemary exhibited a high radical scavenging activity $(11.741 \pm 0.004 \mu \mathrm{g} / \mathrm{ml})$ close to those of the tested synthetic antioxidants viz., Ascorbic acid $\quad(3.036 \pm 0.217 \mu \mathrm{g} / \mathrm{ml}), \quad$ BHA $(7.492 \pm 0.057 \mu \mathrm{g} / \mathrm{ml})$ and BHT $(21.211 \pm 2.593 \mu \mathrm{g} / \mathrm{ml})$. Lugemwa et al., (2013) also reported DPPH radical scavenging activities of several herbs and they found that oregano and rosemary showing LC 50 value of 592.5 and $414.2 \mathrm{mg}$ of phenol/L respectively. The results of the present study can be compared with the findings of Khanum et al., (2011) where they found that oregano exhibited maximum radical scavenging activity of $88.2 \%$ and $82.3 \%$ for aqueous and ethanolic extracts at $50 \mathrm{ppm}$ concentration respectively. 
Ferric reducing antioxidant power assay rosemary and oregano

In present investigation of rosemary and oregano were assayed for their ferric reducing activity at different concentration (100$500 \mu \mathrm{g} / \mathrm{mL}$ ) and the results are depicted in Table.3. The activity was compared with reference standard BHT at a concentration of $200 \mathrm{mg} / \mathrm{L}$. The reducing power of both the compounds increased with the increase in concentration $(\mathrm{p}<0.05)$. At the same concentration used, the descending order of FRAP of the compounds were as follows: Rosemary > Oregano.

The synthetic antioxidant BHTs showed maximum absorbance of 1.283 Abs at 200mg/L whereas Rosemary and Oregano showed higher ferric reducing capability of 2.162 and $1.379 \mathrm{Abs}$ respectively at $500 \mathrm{mg} / \mathrm{mL}$. The findings were agreed with Fernandes et al., (2016) who reported that rosemary and oregano showed ferric reducing ability of $361.57 \pm 33.72$ and $472.32 \pm 15.96$ respectively. These findings are not in agreement with those reported by Shan et al., (2005) who noticed oregano extracts (1.01 mmol trolox/g dw) showed higher ferric reducing antioxidant power compared with that of rosemary extracts $(0.38 \mathrm{mmol}$ trolox $/ \mathrm{g}$ $\mathrm{dw})$.

Metal chelating activity of rosemary and oregano

In present investigation of rosemary and oregano were assayed for their metal chelating activity at different concentration and the results were depicted in Table.3. The activity was compared with synthetic metal chelator (EDTA) at $1.0 \mathrm{mM}$. The maximum metal chelating activity of rosemary and oregano were seen at $500 \mathrm{mg} / \mathrm{L}$ which was $50.28 \%$ and $39.16 \%$ whereas EDTA at $1.0 \mathrm{mM}$ showed $85.65 \%$. The metal chelating ability of both the compounds was very less at lower concentrations but increased with increase in concentration. The metal chelation activity of rosemary extract were checked by El-Beltagi and Badawi (2013) and they reported that the percentages of metal scavenging capacity at $200 \mu \mathrm{g} / \mathrm{ml}$ of tested methanol extracts of rosemary and EDTA was found to be 38.31 and $51.21 \%$ respectively. Bejaoui et al., (2013) studied a substantial metal chelating capacity of methnolic extract, ethanolic extract and water extract and documented metal chelating activity of $76.98,48.95$ and $31.68 \%$ respectively.

\section{In vitro antimicrobial activity of Rosemary and Oregano}

The antimicrobial activity of rosemary and oregano were checked at $5 \mathrm{mg} / \mathrm{ml}$ and the results are shown in Table 4. Among the two extracts tested against gram+ve and gram-ve bacteria, rosemary showed higher antimicrobial activity compared with oregano. The present results of the study can be compared with the findings of Zhang et al., (2016) who had investigated antimicrobial activity of rosemary at $5,10,20,40 \mathrm{mg} / \mathrm{ml}$ concentration against E.coli and Pseudomonas fluorescens.

The zone of inhibition was found to be 12.13, 13.84, 16.81, 17.54 for E.coli and 9.40, 11.45, 13.05 and 17.73 for Pseudomonas fluorescens at $5, \quad 10,20,40 \mathrm{mg} / \mathrm{ml}$ concentration respectively. Seydim and Sarikus (2007) reported that oregano were tested against E.coli, Staphylococcus and Salmonella enteritidis and the zone of inhibition were found to be $777.72,957.25$ and $883.34 \mathrm{~mm}^{2}$ respectively at $4 \%$ concentration. The higher antimicrobial activity of rosemary and oregano may be presence of core compounds like Thymol and Carvacrol which might play an important role in their antimicrobial activity. 


\section{Proximate composition of Indian mackerel}

In present study the proximate composition of Indian mackerel had moisture content of $74.48 \%$, protein content of $17.02 \%$, Fat content of $6.52 \%$ and Ash content of $1.30 \%$. Among this composition moisture content was very high compared to protein, fat, ash. The present study results were compared to the Sofi et al., (2015), who documented that proximate composition of Indian mackerel were shown $71.02 \%$ of moisture, $21.02 \%$ of protein, $6.09 \%$ of fat and $1.20 \%$ of ash respectively. The results of this study were in agreement with the findings of Lakshmisha $e t$ al., (2014) for moisture and lipid content ranged between 71.31 to $76.63 \%$ and 5.90 to $7.25 \%$ respectively.

\section{Chemical analysis}

\section{Changes in peroxide value}

In the present investigation, peroxide value of all the treatments increases throughout the storage period showed Table.5. In this study, $\mathrm{PV}$ value initially in all treatment groups were similar and increased during the increasing of storage period. Chitosan treated sample showed significantly $(\mathrm{p}<0.05)$ higher PV value compared to the BHT, rosemary and oregano.

The increase in PV in all the samples indicated that, the samples were in propagation stage of lipid oxidation with a lower rate of decomposition of hydroperoxides. The increase in peroxide value of Indian mackerel during ice storage was also reported by Sofi $e t$ al., (2015). Active packaging with chitosan film will help in reduction of hydroperoxide formation as reported by Coban and Pelin Can, (2013) and they found that primary lipid oxidation can be minimized by active packaging film containing rosemary extract in smoked rainbow trout. The inhibition of peroxides was concentration-dependent which showed a direct relationship between the polyphenolic concentration and the inhibitory efficiency as studied by Bensid et al., (2014) who reported that beheaded anchovy treated with oregano lowers the rate of lipid oxidation by 1.5 times than that of untreated $\mathrm{s}$ amples. Other researchers also found that oregano was effective in controlling primary lipid oxidation as documented by Tsimidou et al., (1995) who reported that $0.5 \%$ oregano having same effect as BHT at $200 \mathrm{ppm}$.

\section{Changes in Thiobarbituric acid (TBA) during ice storage}

The TBA value was used to measure the rancidity in fish and fishery products. Rancidity in fishery products was measured in terms of malonaldehyde content. In the present study, changes in TBA content of chitosan treated mackerel steaks during ice storage were represented in Table.6. The chitosan treated sample were showed significantly $(\mathrm{p}<0.05)$ higher TBA value compared to rosemary and oregano treated groups.

Li et al., (2013) reported that chitosan film coating used directly on the surface of fish might act as barrier between fish meat and its surroundings, thus cutting down diffusion of oxygen to the fish meat surfaces. Bensid et al., (2014) reported that TBA value decreases with the effect of oregano on gutted and beheaded anchovy.

The lowering in TBA value for control and oregano treated samples were found to be 8.77 and $4.81 \mathrm{mg}$ malonaldehyde/ $\mathrm{kg}$ of sample at the end of 12 days of storage. Ozogul et al., (2010) observed the prevention of lipid oxidation using rosemary extract. They reported that the TBA formation in 1 and $2 \%$ rosemary treated sample were found to be 1.49 and $0.65 \mathrm{mg}$ malonaldehyde $/ \mathrm{kg}$ sample respectively at the end of 20 days of storage. 
Int.J.Curr.Microbiol.App.Sci (2018) 7(10): 2875-2890

Table.1 Biochemical changes of control and chitosan treated samples

\begin{tabular}{c|c|c|c|c|}
$\begin{array}{c}\text { Storage } \\
\text { period } \\
\text { (Days) }\end{array}$ & $\begin{array}{c}\text { Control } \\
\text { PV (meq } \mathrm{O}_{2} / \mathrm{kg} \text { of } \\
\text { fat) }\end{array}$ & $\begin{array}{c}\text { TBA(mg of } \\
\text { MA/kg of } \\
\text { sample) }\end{array}$ & $\begin{array}{c}\mathrm{PV} \text { (meq } \\
\mathrm{O}_{2} / \mathrm{kg} \text { of fat) }\end{array}$ & $\begin{array}{c}\text { TBA(mg of } \\
\text { MA/kg of } \\
\text { sample) }\end{array}$ \\
\hline 0 & $1.50 \pm 0.07^{\mathrm{b}}$ & $0.26 \pm 0.11^{\mathrm{b}}$ & $1.20 \pm 0.05^{\mathrm{a}}$ & $0.22 \pm 0.18^{\mathrm{a}}$ \\
\hline $\mathbf{0}$ & $3.26 \pm 0.07^{\mathrm{b}}$ & $0.76 \pm 0.26^{\mathrm{b}}$ & $1.86 \pm 0.16^{\mathrm{a}}$ & $0.59 \pm 0.32^{\mathrm{a}}$ \\
\hline $\mathbf{6}$ & $5.96 \pm 0.34^{\mathrm{b}}$ & $1.30 \pm 0.12^{\mathrm{b}}$ & $2.79 \pm 0.23^{\mathrm{a}}$ & $1.02 \pm 0.30^{\mathrm{a}}$ \\
\hline 9 & $10.25 \pm 0.14^{\mathrm{b}}$ & $1.52 \pm 0.19^{\mathrm{b}}$ & $3.65 \pm 0.89^{\mathrm{a}}$ & $1.25 \pm 0.10^{\mathrm{a}}$ \\
\hline $\mathbf{1 2}$ & $13.30 \pm 0.02^{\mathrm{b}}$ & $1.76 \pm 0.08^{\mathrm{b}}$ & $5.08 \pm 0.12^{\mathrm{a}}$ & $1.47 \pm 0.21^{\mathrm{a}}$ \\
\hline 15 & $15.02 \pm 0.84^{\mathrm{b}}$ & $2.07 \pm 0.29^{\mathrm{b}}$ & $6.27 \pm 0.43^{\mathrm{a}}$ & $1.62 \pm 0.03^{\mathrm{a}}$ \\
\hline
\end{tabular}

*Each value is represented by the mean $\pm \mathrm{SD}$ of $\mathrm{n}=3$

abcd Indicate significant difference among treatments $(\mathrm{p}<0.05)$

Table.2 Microbial and Sensory changes of control and chitosan treated samples

\begin{tabular}{|c|c|c|c|c|}
\hline $\begin{array}{c}\text { Storage } \\
\text { period } \\
\text { (Days) }\end{array}$ & TPC (cfu/gram of meat) & \multicolumn{2}{|c|}{ Sensory } \\
\hline $\mathbf{0}$ & $4.65 \pm 0.07^{\mathrm{b}}$ & $4.06 \pm 0.14^{\mathrm{a}}$ & $9.00 \pm 0.02^{\mathrm{a}}$ & $9.26 \pm 0.15^{\mathrm{b}}$ \\
\hline $\mathbf{3}$ & $5.29 \pm 0.08^{\mathrm{b}}$ & $4.72 \pm 0.11^{\mathrm{a}}$ & $8.02 \pm 0.07^{\mathrm{a}}$ & $8.35 \pm 0.15^{\mathrm{b}}$ \\
\hline $\mathbf{6}$ & $6.49 \pm 0.15^{\mathrm{b}}$ & $5.62 \pm 0.03^{\mathrm{a}}$ & $7.02 \pm 0.03^{\mathrm{a}}$ & $7.89 \pm 0.31^{\mathrm{b}}$ \\
\hline 9 & $7.72 \pm 0.27^{\mathrm{b}}$ & $6.27 \pm 0.14^{\mathrm{a}}$ & $5.89 \pm 0.20^{\mathrm{a}}$ & $6.26 \pm 0.40^{\mathrm{b}}$ \\
\hline 12 & $9.28 \pm 0.13^{\mathrm{b}}$ & $6.80 \pm 0.27^{\mathrm{a}}$ & $5.02 \pm 0.41^{\mathrm{a}}$ & $5.82 \pm 0.03^{\mathrm{b}}$ \\
\hline 15 & $10.19 \pm 0.33^{\mathrm{b}}$ & $7.73 \pm 0.28^{\mathrm{a}}$ & $3.68 \pm 0.12^{\mathrm{a}}$ & $5.62 \pm 0.23^{\mathrm{b}}$ \\
\hline
\end{tabular}

*Each value is represented by the mean $\pm \mathrm{SD}$ of $\mathrm{n}=3$

abcd Indicate significant difference among treatments $(\mathrm{p}<0.05)$

Table.3 Antioxidant activity of Rosemary and Oregano

\begin{tabular}{|c|}
\hline $\begin{array}{l}\text { Antioxidant } \\
\text { activity }\end{array}$ \\
\hline 100ppm \\
\hline $200 \mathrm{ppm}$ \\
\hline 300ppm \\
\hline $400 \mathrm{ppm}$ \\
\hline 500ppm \\
\hline $\begin{array}{c}\text { BHT }(200 \mathrm{ppm}) \\
\text { EDTA }(1.0 \mathrm{~mm})\end{array}$ \\
\hline
\end{tabular}

\begin{tabular}{|l|l|l|l|}
\hline \multicolumn{2}{|c|}{ DPPH } & \\
\hline Rosemary & Oregano & Ro \\
\hline $77.37 \pm 0.77^{\mathrm{d}}$ & $62.86 \pm 0.67^{\mathrm{e}}$ & 0.52 \\
\hline $76.54 \pm 0.35^{\mathrm{d}}$ & $60.38 \pm 0.57^{\mathrm{d}}$ & 0.86 \\
\hline $75.17 \pm 0.22^{\mathrm{c}}$ & $58.16 \pm 0.76^{\mathrm{c}}$ & 1.28 \\
\hline $73.18 \pm 0.72^{\mathrm{b}}$ & $56.03 \pm 0.38^{\mathrm{b}}$ & 1.8 \\
\hline $69.92 \pm 0.65^{\mathrm{a}}$ & $54.01 \pm 0.81^{\mathrm{a}}$ & 2.16 \\
\hline $82.69 \pm 0.46$ & $82.69 \pm 0.46$ & 1.28 \\
\hline
\end{tabular}

\begin{tabular}{|l|}
\hline Ros \\
\hline 0.5 \\
\hline 0.86 \\
\hline 1.28 \\
\hline 1.849 \\
\hline 1.28 \\
\hline
\end{tabular}

FRAP

Rosemary Oregano

$0.528 \pm 0.03^{\mathrm{a}} \quad 0.052 \pm 0.01^{\mathrm{a}}$

$0.861 \pm 0.07^{\mathrm{b}} \quad 0.426 \pm 0.08^{\mathrm{b}}$

$1.287 \pm 0.26^{\mathrm{c}}$

$0.780 \pm 0.06_{c}$

$1.849 \pm 0.06^{\mathrm{d}} \quad 0.990 \pm 0.01^{\mathrm{d}}$

$2.162 \pm 0.06^{\mathrm{e}}$

$1.379 \pm 0.04^{\mathrm{e}}$

$1.282 \pm 0.06$

$1.282 \pm 0.06$

DPPH- Diphenyl-1 picrylhydrazyl: FRAP-Ferric reducing power assay:

MCA-metal chelating activity

*Each value is represented by the mean $\pm S D$ of $n=3$

${ }^{\text {abcd }}$ Indicate significant difference among treatments $(\mathrm{p}<0.05)$. 
Int.J.Curr.Microbiol.App.Sci (2018) 7(10): 2875-2890

Table.5 Biochemical changes in Indian mackerel steaks with the effect of chitosan treated Rosemary and Oregano during chill storage

\begin{tabular}{|c|c|c|c|c|c|c|c|c|c|}
\hline \multirow{6}{*}{$\begin{array}{l}\text { Parameter } \\
\text { PV(mg of hydro } \\
\text { peroxide/kg of sample) }\end{array}$} & \multirow[t]{2}{*}{ Treatment } & \multicolumn{8}{|c|}{ Storage days } \\
\hline & & 0 & 3 & 6 & 9 & 12 & 15 & 18 & 21 \\
\hline & Chitosan & $1.08 \pm 0.06^{\mathrm{b}}$ & $3.59 \pm 0.16^{\mathrm{c}}$ & $6.60 \pm 0.36^{\mathrm{d}}$ & $8.40 \pm 0.34^{\mathrm{d}}$ & $10.38 \pm 0.23^{\mathrm{d}}$ & $11.46 \pm 0.17^{\mathrm{d}}$ & $12.67 \pm 0.18^{d}$ & $14.77 \pm 0.16^{\mathrm{d}}$ \\
\hline & Chitosan +BHT & $0.90 \pm 0.06^{\mathrm{a}}$ & $2.47 \pm 0.11^{\mathrm{a}}$ & $4.16 \pm 0.14^{\mathrm{a}}$ & $6.21 \pm 0.16^{\mathrm{a}}$ & $8.13 \pm 0.10^{\mathrm{a}}$ & $9.19 \pm 0.14^{\mathrm{a}}$ & $10.22 \pm 0.14^{\mathrm{a}}$ & $11.80 \pm 0.12_{\mathrm{a}}$ \\
\hline & $\begin{array}{l}\text { Chitosan } \\
+ \text { Rosemary }\end{array}$ & $0.96 \pm 0.06^{\mathrm{a}}$ & $2.79 \pm 0.18^{b}$ & $4.66 \pm 0.34^{b}$ & $6.43 \pm 0.18^{b}$ & $8.41 \pm 0.19^{\mathrm{b}}$ & $9.65 \pm 0.18^{b}$ & $10.60 \pm 0.11^{\mathrm{b}}$ & $11.97 \pm 0.26^{\mathrm{ab}}$ \\
\hline & $\begin{array}{l}\text { Chitosan + } \\
\text { Oregano }\end{array}$ & $0.96 \pm 0.06^{\mathrm{a}}$ & $2.86 \pm 0.14^{\mathrm{b}}$ & $4.86 \pm 0.13^{\mathrm{bc}}$ & $6.61 \pm 0.26^{\mathrm{c}}$ & $8.62 \pm 0.27^{c}$ & $9.85 \pm 0.11^{\mathrm{c}}$ & $10.86 \pm 0.10^{\mathrm{bc}}$ & $12.46 \pm 0.35^{\mathrm{c}}$ \\
\hline \multirow{4}{*}{$\begin{array}{l}\text { TBA(mg MA/kg of } \\
\text { sample) }\end{array}$} & Chitosan & $0.37 \pm 0.020^{\mathrm{a}}$ & $0.64 \pm 0.015^{b}$ & $0.84 \pm 0.025^{\mathrm{b}}$ & $1.29 \pm 0.005^{\mathrm{c}}$ & $1.70 \pm 0.005^{\mathrm{b}}$ & $2.22 \pm 0.010^{\mathrm{d}}$ & $2.56 \pm 0.000^{\mathrm{d}}$ & $2.81 \pm 0.000^{\mathrm{d}}$ \\
\hline & Chitosan +BHT & $0.36 \pm 0.026^{\mathrm{a}}$ & $0.59 \pm 0.015^{\mathrm{ab}}$ & $0.73 \pm 0.020^{\mathrm{a}}$ & $0.96 \pm 0.011^{\mathrm{a}}$ & $1.24 \pm 0.010^{\mathrm{a}}$ & $1.57 \pm 0.005^{\mathrm{a}}$ & $1.74 \pm 0.025^{\mathrm{a}}$ & $2.05 \pm 0.005^{\mathrm{a}}$ \\
\hline & $\begin{array}{l}\text { Chitosan } \\
\text { +Rosemary }\end{array}$ & $0.35 \pm 0.015^{\mathrm{a}}$ & $0.56 \pm 0.020^{\mathrm{a}}$ & $0.73 \pm 0.032^{\mathrm{a}}$ & $0.98 \pm 0.005^{\mathrm{a}}$ & $1.25 \pm 0.010^{\mathrm{a}}$ & $1.61 \pm 0.010^{\mathrm{b}}$ & $1.84 \pm 0.062^{\mathrm{b}}$ & $2.12 \pm 0.005^{\mathrm{b}}$ \\
\hline & $\begin{array}{l}\text { Chitosan + } \\
\text { Oregano }\end{array}$ & $0.36 \pm 0.026^{\mathrm{a}}$ & $0.63 \pm 0.050^{\mathrm{b}}$ & $0.73 \pm 0.025^{\mathrm{a}}$ & $1.01 \pm 0.025^{\mathrm{b}}$ & $1.37 \pm 0.025^{\mathrm{b}}$ & $1.68 \pm 0.005^{\mathrm{c}}$ & $1.91 \pm 0.025^{\mathrm{c}}$ & $2.22 \pm 0.005^{\mathrm{c}}$ \\
\hline \multirow[t]{4}{*}{ FFA(\% of oleic acid) } & Chitosan & $1.19 \pm 0.34^{\mathrm{c}}$ & $2.59 \pm 0.12^{c}$ & $4.52 \pm 0.14^{\mathrm{d}}$ & $5.26 \pm 0.16^{\mathrm{d}}$ & $6.85 \pm 0.28^{\mathrm{d}}$ & $7.58 \pm 0.11^{\mathrm{d}}$ & $8.74 \pm 0.18^{\mathrm{d}}$ & $10.24 \pm 0.10^{\mathrm{d}}$ \\
\hline & Chitosan +BHT & $0.89 \pm 0.22^{b}$ & $1.85 \pm 0.14^{\mathrm{a}}$ & $2.92 \pm 0.11^{\mathrm{a}}$ & $3.68 \pm 0.18^{\mathrm{a}}$ & $4.13 \pm 0.14^{\mathrm{a}}$ & $5.39 \pm 0.10^{\mathrm{a}}$ & $6.21 \pm 0.10^{\mathrm{a}}$ & $8.75 \pm 0.13^{\mathrm{a}}$ \\
\hline & $\begin{array}{l}\text { Chitosan } \\
\text { +Rosemary }\end{array}$ & $0.89 \pm 0.22^{\mathrm{b}}$ & $2.14 \pm 0.12^{\mathrm{b}}$ & $3.21 \pm 0.20^{\mathrm{b}}$ & $4.65 \pm 0.15^{\mathrm{b}}$ & $5.41 \pm 0.25^{\mathrm{b}}$ & $6.24 \pm 0.20^{b}$ & $7.21 \pm 0.12^{b}$ & $9.23 \pm 0.10^{b}$ \\
\hline & $\begin{array}{l}\text { Chitosan + } \\
\text { Oregano }\end{array}$ & $0.67 \pm 0.22^{\mathrm{a}}$ & $2.29 \pm 0.11^{\mathrm{ab}}$ & $3.69 \pm 0.12^{c}$ & $4.86 \pm 0.10^{c}$ & $5.61 \pm 0.27^{b}$ & $6.58 \pm 0.20^{\mathrm{bc}}$ & $7.55 \pm 0.11^{\mathrm{c}}$ & $9.60 \pm 0.15^{\mathrm{ab}}$ \\
\hline \multirow{4}{*}{$\begin{array}{l}\text { TMAN(mgN/100g of } \\
\text { sample) }\end{array}$} & Chitosan & $1.63 \pm 0.12^{\mathrm{b}}$ & $0.35 \pm 0.015^{\mathrm{a}}$ & $6.35 \pm 0.14^{c}$ & $9.81 \pm 0.18^{c}$ & $10.50 \pm 0.16^{\mathrm{c}}$ & $13.75 \pm 0.13^{\mathrm{c}}$ & $15.45 \pm 0.13^{\mathrm{d}}$ & $20.18 \pm 0.14^{d}$ \\
\hline & Chitosan +BHT & $1.43 \pm 0.06^{\mathrm{ab}}$ & $2.52 \pm 0.18^{\mathrm{a}}$ & $5.42 \pm 0.28^{\mathrm{a}}$ & $6.40 \pm 0.22^{\mathrm{a}}$ & $6.39 \pm 0.18^{\mathrm{a}}$ & $9.77 \pm 0.11^{\mathrm{a}}$ & $12.52 \pm 0.12^{\mathrm{a}}$ & $15.41 \pm 0.08^{\mathrm{a}}$ \\
\hline & $\begin{array}{l}\text { Chitosan } \\
\text { +Rosemary }\end{array}$ & $1.62 \pm 0.21^{\mathrm{b}}$ & $3.51 \pm 0.18^{b}$ & $5.68 \pm 0.12^{\mathrm{ab}}$ & $6.74 \pm 0.08^{\mathrm{ab}}$ & $8.81 \pm 0.13^{\mathrm{b}}$ & $10.32 \pm 0.11^{\mathrm{b}}$ & $14.31 \pm 0.54^{\mathrm{b}}$ & $16.82 \pm 0.17^{c}$ \\
\hline & $\begin{array}{l}\text { Chitosan }+ \\
\text { Oregano }\end{array}$ & $1.63 \pm 0.22^{\mathrm{b}}$ & $3.39 \pm 0.06^{\mathrm{ab}}$ & $5.79 \pm 0.16^{\mathrm{ab}}$ & $6.80 \pm 0.17 b$ & $8.80 \pm 0.17^{\mathrm{b}}$ & $10.53 \pm 0.17^{b}$ & $14.80 \pm 0.18^{c}$ & $16.79 \pm 0.18^{c}$ \\
\hline \multirow{4}{*}{$\begin{array}{l}\text { TVBN (mgN/100g of } \\
\text { sample) }\end{array}$} & Chitosan & $2.56 \pm 0.14^{\mathrm{c}}$ & $5.38 \pm 0.20^{c}$ & $9.35 \pm 0.24^{c}$ & $13.51 \pm 0.27^{\mathrm{c}}$ & $18.65 \pm 0.14^{c}$ & $25.45 \pm 0.21^{\mathrm{d}}$ & $28.40 \pm 0.15^{\mathrm{d}}$ & $32.16 \pm 0.18^{d}$ \\
\hline & Chitosan +BHT & $1.60 \pm 0.20^{\mathrm{a}}$ & $3.57 \pm 0.14^{\mathrm{a}}$ & $7.37 \pm 0.15^{\mathrm{a}}$ & $10.29 \pm 0.15^{\mathrm{a}}$ & $16.57 \pm 0.14^{\mathrm{a}}$ & $18.43 \pm 0.18^{\mathrm{a}}$ & $20.13 \pm 0.10^{\mathrm{a}}$ & $25.47 \pm 0.15^{\mathrm{a}}$ \\
\hline & $\begin{array}{l}\text { Chitosan } \\
\text { +Rosemary }\end{array}$ & $1.67 \pm 0.13^{\mathrm{a}}$ & $4.37 \pm 0.15^{b}$ & $8.39 \pm 0.16^{\mathrm{b}}$ & $11.22 \pm 0.18^{\mathrm{b}}$ & $17.610 .10^{\mathrm{b}}$ & $20.46 \pm 0.17^{b}$ & $24.21 \pm 0.12^{\mathrm{b}}$ & $26.34 \pm 0.11^{\mathrm{b}}$ \\
\hline & $\begin{array}{l}\text { Chitosan + } \\
\text { Oregano }\end{array}$ & $1.76 \pm 0.12^{\mathrm{ab}}$ & $4.40 \pm 0.23^{b}$ & $8.21 \pm 0.13^{b}$ & $11.54 \pm 0.23^{\mathrm{b}}$ & $17.59 \pm 0.11^{\mathrm{b}}$ & $21.59 \pm 0.25^{\mathrm{c}}$ & $27.55 \pm 0.10^{c}$ & $28.57 \pm 0.14^{b}$ \\
\hline \multirow[t]{4}{*}{$\mathrm{pH}$} & Chitosan & $6.37 \pm 0.04^{\mathrm{c}}$ & $6.52 \pm 0.09^{c}$ & $6.63 \pm 0.16^{\mathrm{c}}$ & $6.67 \pm 0.13^{\mathrm{c}}$ & $6.82 \pm 0.15^{\mathrm{b}}$ & $6.79 \pm 0.16^{\mathrm{b}}$ & $6.92 \pm 0.32^{c}$ & $7.23 \pm 0.18^{\mathrm{c}}$ \\
\hline & Chitosan +BHT & $6.19 \pm 0.20^{\mathrm{a}}$ & $6.25 \pm 0.12^{\mathrm{a}}$ & $6.42 \pm 0.16^{\mathrm{a}}$ & $6.50 \pm 0.18^{\mathrm{a}}$ & $6.61 \pm 0.17^{\mathrm{a}}$ & $6.69 \pm 0.16^{\mathrm{a}}$ & $6.72 \pm 0.29^{\mathrm{a}}$ & $6.77 \pm 0.10^{\mathrm{a}}$ \\
\hline & $\begin{array}{l}\text { Chitosan } \\
\text { +Rosemary }\end{array}$ & $6.28 \pm 0.19^{b}$ & $6.48 \pm 0.12^{b}$ & $1.57 \pm 0.17^{b}$ & $1.59 \pm 0.18^{\mathrm{ab}}$ & $6.65 \pm 0.15^{\mathrm{a}}$ & $6.72 \pm 0.16^{\mathrm{ab}}$ & $6.74 \pm 0.22^{\mathrm{a}}$ & $6.80 \pm 0.22^{\mathrm{ab}}$ \\
\hline & $\begin{array}{l}\text { Chitosan + } \\
\text { Oregano }\end{array}$ & $6.29 \pm 0.13^{b}$ & $6.49 \pm 0.17^{b}$ & $6.52 \pm 0.19^{b}$ & $6.60 \pm 0.18^{\mathrm{bc}}$ & $6.69 \pm 0.17^{\mathrm{a}}$ & $6.74 \pm 0.15^{b}$ & $6.81 \pm 0.17^{b}$ & $6.93 \pm 0.26^{b}$ \\
\hline
\end{tabular}

*Each value is represented by the mean $\pm \mathrm{SD}$ of $\mathrm{n}=3$ and ${ }^{\text {abcd }}$ Indicate significant difference among treatments $(\mathrm{p}<0.05)$ 
Int.J.Curr.Microbiol.App.Sci (2018) 7(10): 2875-2890

Table.6 Microbial and sensory changes in Indian mackerel steaks with the effect of chitosan treated Rosemary and Oregano during chill storage

\begin{tabular}{|c|c|c|c|c|c|c|c|c|c|}
\hline \multirow[t]{2}{*}{ Parameter } & \multirow[t]{2}{*}{ Treatment } & \multicolumn{8}{|c|}{ Storage Days } \\
\hline & & 0 & 3 & 6 & 9 & 12 & 15 & 18 & 21 \\
\hline \multirow[t]{4}{*}{ TPC } & Chitosan & $4.04 \pm 0.14^{\mathrm{a}}$ & $4.64 \pm 0.11^{\mathrm{a}}$ & $5.18 \pm 0.13^{\mathrm{a}}$ & $6.27 \pm 0.13^{\mathrm{a}}$ & $6.80 \pm 0.13^{b}$ & $7.10 \pm 0.13^{b}$ & $7.43 \pm 0.13^{b}$ & $8.61 \pm 0.14^{c}$ \\
\hline & $\begin{array}{l}\text { Chitosan } \\
+\mathrm{BHT}\end{array}$ & $4.43 \pm 0.10^{\mathrm{a}}$ & $4.86 \pm 0.11^{b}$ & $5.35 \pm 0.20^{c}$ & $6.40 \pm 0.15^{c}$ & $7.02 \pm 0.11^{\mathrm{c}}$ & $7.21 \pm 0.24^{\mathrm{c}}$ & $7.89 \pm 0.11^{\mathrm{d}}$ & $8.88 \pm 0.10^{d}$ \\
\hline & $\begin{array}{l}\text { Chitosan } \\
\text { +Rosemary }\end{array}$ & $4.03 \pm 0.26^{\mathrm{a}}$ & $4.69 \pm 0.14^{\mathrm{a}}$ & $5.32 \pm 0.10^{c}$ & $6.37 \pm 0.05^{b}$ & $6.78 \pm 0.12^{\mathrm{a}}$ & $6.86 \pm 0.18^{\mathrm{a}}$ & $7.12 \pm 0.16^{\mathrm{a}}$ & $8.39 \pm 0.20^{\mathrm{a}}$ \\
\hline & $\begin{array}{l}\text { Chitosan + } \\
\text { Oregano }\end{array}$ & $4.19 \pm 0.15^{\mathrm{a}}$ & $4.61 \pm 0.26^{\mathrm{a}}$ & $5.27 \pm 0.08^{b}$ & $6.35 \pm 0.18^{b}$ & $\begin{array}{l}6.82 \pm 0.30^{\mathrm{a}} \\
\mathrm{b}\end{array}$ & $\begin{array}{l}6.97 \pm 0.08^{\mathrm{a}} \\
\mathrm{b}\end{array}$ & $7.55 \pm 0.08^{b}$ & $8.55 \pm 0.10^{b}$ \\
\hline \multirow{4}{*}{$\begin{array}{l}\text { Over all } \\
\text { cceptability }\end{array}$} & Chitosan & $9.26 \pm 0.15^{\mathrm{a}}$ & $8.16 \pm 0.15^{a}$ & $7.16 \pm 0.15^{\mathrm{a}}$ & $6.38 \pm 0.17^{b}$ & $6.26 \pm 0.11^{\mathrm{a}}$ & $5.46 \pm 0.20^{\mathrm{a}}$ & $4.33 \pm 0.15^{b}$ & $3.33 \pm 0.15^{b}$ \\
\hline & $\begin{array}{l}\text { Chitosan } \\
+\mathrm{BHT}\end{array}$ & $9.50 \pm 0.10^{\mathrm{a}}$ & $8.41 \pm 0.18^{a}$ & $7.41 \pm 0.20^{\mathrm{a}}$ & $7.13 \pm 0.11^{\mathrm{a}}$ & $6.60 \pm 0.26^{\mathrm{a}}$ & $5.60 \pm 0.26^{\mathrm{a}}$ & $5.32 \pm 0.17^{\mathrm{a}}$ & $4.81 \pm 0.14^{\mathrm{a}}$ \\
\hline & $\begin{array}{l}\text { Chitosan } \\
\text { +Rosemary }\end{array}$ & $9.40 \pm 0.20^{\mathrm{a}}$ & $8.30 \pm 0.17^{\mathrm{a}}$ & $7.46 \pm 0.15^{\mathrm{a}}$ & $6.41 \pm 0.18^{b}$ & $6.53 \pm 0.25^{\mathrm{a}}$ & $5.30 \pm 0.10^{\mathrm{a}}$ & $5.21 \pm 0.20^{\mathrm{a}}$ & $4.29 \pm 0.14^{\mathrm{a}}$ \\
\hline & $\begin{array}{l}\text { Chitosan + } \\
\text { Oregano }\end{array}$ & $9.33 \pm 0.15^{\mathrm{a}}$ & $8.20 \pm 0.10^{\mathrm{a}}$ & $7.23 \pm 0.15^{\mathrm{a}}$ & $6.46 \pm 0.20^{b}$ & $6.46 \pm 0.25^{\mathrm{a}}$ & $5.40 \pm 0.10^{\mathrm{a}}$ & $5.01 \pm 0.28^{\mathrm{a}}$ & $4.38 \pm 0.14^{\mathrm{a}}$ \\
\hline
\end{tabular}

*Each value is represented by the mean $\pm S D$ of $n=3$

abcd Indicate significant difference among treatments $(\mathrm{p}<0.05)$ 
Table.4 Antimicrobial activity of rosemary and oregano

\begin{tabular}{|l|l|l|l|}
\hline Microorganisms & \multicolumn{3}{|c|}{ Zone of inhibition in mm } \\
\hline S. aureus & Oremary & Oregano & Ampicillin \\
\hline B.subtilis & $19.56 \pm 1.23$ & $15.37 \pm 0.59$ & $38.16 \pm 0.83$ \\
\hline P.fluorescens & $18.49 \pm 0.34$ & $15.69 \pm 0.28$ & $32.56 \pm 1.56$ \\
\hline S.typium & $11.03 \pm 0.89$ & $9.05 \pm 0.14$ & $30.75 \pm 0.12$ \\
\hline E.coli & $20.72 \pm 0.43$ & $11.09 \pm 0.71$ & $33.26 \pm 0.51$ \\
\hline & $10.37 \pm 0.03$ & $12.03 \pm 0.37$ & $24.08 \pm 0.86$
\end{tabular}

\section{Changes in Free Fatty Acid (FFA) content during ice storage}

In the present investigation, free fatty acid of all the treatments increases throughout the storage period was shown Table.5. FFA value was initially similar in all treatment groups during increase storage period chitosan treated sample shown significantly $(\mathrm{p}<0.05)$ higher than oregano, rosemary and BHT. The present Ozogul et al., (2010) observed the effect of prevention of lipid hydrolysis by using rosemary extract and the results were in agreement with the present study that FFA formation of $1 \%$ rosemary treated sample were found to be 5.98 and $2 \%$ rosemary treated sample were found to be $6.13 \%$ of oleic acid/ $\mathrm{kg}$ of fat respectively at the end of 20 days of ice storage. Bensid et al., (2014) reported that the oregano treated gutted and beheaded anchovy during chill storage. They stated that the FFA formation of oregano treated sample was found to be $5.39 \%$ of oleic $\mathrm{acid} / \mathrm{kg}$ of fat respectively at 12 days ice condition whereas in control sample free fatty formation was $5.98 \%$ of oleic acid $/ \mathrm{kg}$ of fat respectively. These results might be attributed to the effect of phenolic compounds in plant extracts, which lowers liberation of free fatty acids due to the inhibition of enzymatic action. Reesha et al., (2015) studied that chitosan / low density polyethylene (LDPE) composite films in tilapia during chill storage. They reported that the FFA formation was found to be $11.00 \%$ of oleic acid $/ \mathrm{kg}$ of fat in $1 \%$ chitosan treated samples at 30 days chill storage. It is concluded that rosemary and oregano extracts with chitosan coating helps in lowering the lipid hydrolysis of Indian mackerel steaks during ice storage.

\section{Changes in Trimethylamine Nitrogen (TMA-N) content during ice storage}

Trimethylamine nitrogen (TMA- N) level in fish is an important factor in the subjective evaluation of fish quality because of its close association with fish spoilage (Chang and Creaser, 1976; Love, 1992). In the present study TMA-N values were shown increasing trend throughout the storage period shown Table: 6 . The present results can be compared with the findings of Mohan et al., (2012) who studied the effect of chitosan edible coating on double filleted Indian oil sardine during chilled storage. They reported that initially TMA-N content for $1 \%$ chitosan treated sample was found to be $6.01 \mathrm{mg} \mathrm{N} / 100 \mathrm{~g}$ and reaches maximum of $19.92 \mathrm{mg} \mathrm{N} / 100 \mathrm{~g}$ whereas $2 \%$ chitosan treated sample showed maximum of $17.19 \mathrm{mg} \mathrm{N} / 100 \mathrm{~g}$ in respectively after 30 days of storage period. Ozyurt et al., (2012) studied the effect of rosemary extract on the oxidative stability and biogenic amine formation in sardine during chilled storage. They reported that the TMA-N values were recorded as 22.23 and $18.43 \mathrm{mg} \mathrm{N} / 100 \mathrm{~g}$ for 0.05 and $0.1 \%$ rosemary after 25 days of chilled storage. It can be concluded that treatment of rosemary and oregano extract significantly affected the accumulation of TMA-N content in fish muscle. 


\section{Changes in Total Volatile Base-Nitrogen (TVB-N) content during ice storage}

In the present investigation, TVB-N content of mackerel steaks were shown (Table:5) increase in TVB-N levels in fish may result from deamination of free amino acids, oxidation of amines and degradation of nucleotides by autolytic enzymes and microbial activity (Ocano-Higuera et al., 2011). Li et al., (2013) studied the quality changes of refrigerated red drum fillets using chitosan coating with natural preservative and reported that TVB-N content reaches maximum of 38.17 and $33.69 \mathrm{mg}-\mathrm{N} / 100 \mathrm{~g}$ after 20 days of ice storage for grape seed and tea polyphenols respectively, whereas untreated samples showed TVB-N content of $51.25 \mathrm{mg}-\mathrm{N} / 100 \mathrm{~g}$ at the end of 20 days of ice storage. Polyphenols from natural sources having antimicrobial activity which helps in reduction of bacterial flora in fish and fishery products as reported by Ozogul et al., (2010) who reported that TVB-N content was found to be $34.29 \mathrm{mg}-\mathrm{N} / 100 \mathrm{~g}$ at day 13 for untreated samples whereas 33.64 and 35.82 $\mathrm{mg}-\mathrm{N} / 100 \mathrm{~g}$ at day 17 for 1 and $2 \%$ rosemary extract respectively. The reduction in TVB-N content might be due to antimicrobial activity of rosemary extracts. The present results of the investigation can be compared with the findings of Bensid et al., (2014) who reported that TVB-N content of oregano treated gutted and beheaded anchovy fillets during ice storage was shown maximum of $38.10 \mathrm{mg}$ $\mathrm{N} / 100 \mathrm{~g}$ of sample whereas, untreated samples showed maximum of $60.23 \mathrm{mg}-\mathrm{N} / 100 \mathrm{~g}$ of sample after 12 days ice condition.

\section{Changes in pH during ice storage}

An important determination of fish quality texture measurement and gaping in fish fillets which were influenced by $\mathrm{pH}$ (Love, 1992). The increase of $\mathrm{pH}$ values during the storage period may be attributed to accumulation of alkaline compounds, such as ammonia, which mainly derived from microbial action during fish muscle spoilage. Remya et al., (2016) studied the chitosan based active films used in barracuda packing during chill storage. They reported that the $\mathrm{pH}$ value of chitosan with ginger essential oil was shown 6.9 whereas, untreated group showed 7.3 at the end of storage. Ozyurt et al., (2012) studied that rosemary extract on the oxidative stability and biogenic amine formation in sardine during chilled storage. They documented that maximum $\mathrm{pH}$ values attained by untreated sample was 7.23 whereas $0.05 \%$ and $0.1 \%$ rosemary extract showed $\mathrm{pH}$ values of 7.26 and 6.9 respectively. The present results of oregano treated samples can be correlated with Bensid et al., (2014) who observed that there is steady rise in $\mathrm{pH}$ during the ice storage period. The oregano treated samples showed maximum $\mathrm{pH}$ of 6.93 whereas untreated sample showed 7.3 at the end of 12 day storage.

\section{Changes in Total Plate Count of mackerel steaks during ice storage}

In the present study, changes in TPC content of chitosan treated mackerel steaks with rosemary and oregano during ice storage are represented in Table.7. The present findings can be correlated with the findings of Ozogul et al., (2010) who observed prevention of microbial spoilage in oil sardine by using rosemary extract during 20 days of ice storage. They reported that untreated samples were in acceptable condition up to 10 days whereas $1 \%$ \& $2 \%$ rosemary treated samples where in acceptable condition up to 13 and 17 days respectively. Mohan et al., (2012) studied the chitosan edible coating of double filleted Indian oil sardine during 11 days of ice storage. They found that untreated samples were found in acceptable condition up to $9^{\text {th }}$ day whereas $1 \%$ and $2 \%$ chitosan treated samples were in acceptable condition 
up to 11 days of ice storage. According to the (ICMSF, 1986) total aerobic plate count limit for fresh fish is $10^{7} \mathrm{cfu} / \mathrm{g}$ ( $\left.7 \mathrm{cfu} / \mathrm{g}\right)$. Based on ICMSF, (1986) the results of the present study crossed the limit on 18th day of ice storage for rosemary and oregano treated samples whereas untreated samples reached maximum on $12^{\text {th }}$ day of ice storage.

\section{Changes in organoleptic characteristics of mackerel streaks during ice storage}

The overall acceptability score is the mean of attributes such as color, texture, appearance, flavor and taste. In the present study, overall acceptable scores were depicted in Table.6. The chitosan treated sample shown sensory rejection on $15^{\text {th }}$ day ice storage. Decreasing in sensory score indicated the loss of freshness in samples; this could be due to lipid oxidation and microbial spoilage (Connell, 1995). Cai et al., (2014) studied the quality changes of chitosan coated with ergothioneine in Japanese sea bass. They reported that the chitosan treated sample did not exhibit these characteristics even on the $16^{\text {th }}$ day of storage whereas the uncoated samples were shown the limit of acceptability on $8^{\text {th }}$ day. Bensid et al., (2014) studied the oregano treated gutted and beheaded anchovy during ice storage. They reported that the sensory scores in both control and treated groups declined throughout the 12 days of ice storage.

The DPPH radical scavenging activity of both the compounds showed descending manner, rosemary showed more ferric reducing power than oregano and metal chelating activity of the both compounds was showed less chelation than compared the synthetic compounds. The gram -ve bacteria showed more inhibition zone compared to the gram +ve bacteria in both the compounds. The results indicated that both rosemary and Oregano extracts exhibited good antioxidant and antimicrobial properties by extending the shelf life of Indian mackerel steaks up to 3 days. Among the rosemary extract and oregano extracts, rosemary extract exhibited higher antioxidant and antimicrobial properties than oregano extract.

\section{Acknowledgement}

The authors would like to thank the Vice Chancellor of Sri Venkateswara Veterinary University (SVVU), Tirupati; the Dean of Fishery Science, SVVU, Tirupati and the Associate Dean, College of Fishery science, SVVU, Muthukur for providing facility and support.

\section{References}

Aider, M. 2010. Chitosan application for active bio-based films production and potential in the food industry: Review. LWT-Food Science and Technology, 43 (6): 837-842.

APHA. 1992. Compendium of Methods for the Microbiological Examination of Foods, (Ed.) M. L. Speck, APHA Publication, Washington, USA.

Bauer, A.W., Kirby, W.M.M. and Sherris, J.C. 1966. Antibiotic susceptibility testing by a standardized single disk method. American Journal of Clinical Pathology, 45: 493-496

Béjaoui, A., Chaabane, H., Jemli, M., Boulila, A. and Boussaid, M. 2013. Essential oil composition and antibacterial activity of Origanum vulgare subsp. glandulosum Desf. at different phenological stages. Journal of Medicinal Food, 16 (12): 11151120.

Bensid, A., Ucar, Y. and Bendeddouche, B. 2014. Effect of the icing with thyme, oregano and clove extracts on quality parameters of gutted and beheaded anchovy (Engraulis encrasicholus) during chilled storage. Food Chemistry, 15: 681689.

Bhale, S. D., Xu, Z., Prinyawiwatkul, W., King, J. M. and Godber, J. S. 2007. Oregano 
and rosemary extracts inhibit oxidation of long-chain n-3 fatty acids in menhaden oil. Journal of Food Science, 72 (9):504 508.

Boyd, L.C., Green, D.P., Giesbrecht, F.B. and King, M.F. 1993. Inhibition of oxidative rancidity in frozen cooked fish flakes by tert-butylhydroquinone and rosemary extract. Journal of Science of Food and Agriculture, 61: 87-93.

Boyer, R.F. and Mccleary, C.J. 1987. Superoxide ion as a primary reductant in ascorbate-mediated ferritin iron release. Free Radical Biology and Medicine, 3: 389-395.

Cai, L., Li, X., Wu, X., Lv, Y., Liu, X. and Li, J. 2014. Effect of chitosan coating enriched with ergothioneine on quality changes of Japanese sea bass (Lateolabrax japonicas). Food and Bioprocess Technology, 7 (8): 22812290.

Chang, J. Y. and Creaser, E. H. 1976. A novel manual method for protein-sequence analysis. Biochemical Journal, 157 (1): 77-85.

Çoban, O. and Pelin Can, O. 2013. The effect of active packaging film containing rosemary extract on the quality of smoked rainbow trout (Oncorhynchus mykiss). Journal of Aquatic Food Product Technology, 22 (4):361-370.

Connell, J.J. 1995. Control of Fish Quality, 4th edition. Farnham, Surrey: Fishing News (Books) Ltd. 157: 159-160.

Conway, E. J. 1962. Microdiffusion Analysis of Volumetric Error, 5th ed. Crospy Lockwood and Son Ltd., London.

Dornan, H.J.D., Kosar, M., Kahlos, K., Holm, Y. and Hiltunen, R. 2003. Antioxidant properties and composition of aqueous extracts from Mentha species, hybrids, varieties, and cultivars. Journal of Agricultural and Food Chemistry, 51: 4563-4569.

Duan, J., Cherian, G. and Zhao, Y. 2010. Quality enhancement in fresh and frozen lingcod (Ophiodon elongates) fillets by employment of fish oil incorporated chitosan coating. Food Chemistry, 119: 524-532.

El-Beltagi, H. S. and Badawi, M. H. 2013. Comparison of antioxidant and antimicrobial properties for Ginkgo biloba and rosemary (Rosmarinus officinalis L.) from Egypt. Notulae Botanicae Horti Agrobotanici ClujNapoca, 41 (1): 126.

Fernandes, R. P. P., Trindade, M. A., Tonin, F. G., Lima, C. G., Pugine, S. M. P., Munekata, P. E. S. and de Melo, M. P. 2016. Evaluation of antioxidant capacity of 13 plant extracts by three different methods: cluster analyses applied for selection of the natural extracts with higher antioxidant capacity to replace synthetic antioxidant in lamb burgers. Journal of Food Science and Technology, 53 (1): 451-460.

Hendel, N., Larous, L. and Belbey, L. 2016. Antioxidant activity of rosemary (Rosmarinus officinalis) and its in vitro inhibitory effect on Penicillium digitatum. International Food Research Journal, 23 (4): 1725-1732

Hernandez, E., Ponce-Alquicira, E., JaramilloFlores, M.E. and Guerrero-legarret, I. 2009. Antioxidant effect of rosemary (Rosmarinus officinalis L.) and oregano (Origanum vulgare L.) extracts on TBARS and colour of model raw pork batters. Meat Science, 81:410-417.

ICMSF. 1986. Sampling for microbiological analysis: Principles and specific applications. Microorganisms in food. International Commission on the Microbiological Specification of Foods. Toronto Press, Toronto, Canada, 7.

Indian standard, Indian standard Institutions 1971. Guide for sensory eualuation of foods (IS 6273 part I and part II) Manak Bhawan, New Delhi.

Jacobs, M.B. 1958. The chemical analysis of foods and food products. Krieger Publication Co., New York, UK. 393394.

Kanatt, S. R., Rao, M. S., Chawla, S. P. and Sharma, A. 2012. Active chitosan- 
polyvinyl alcohol films with natural extracts. Food Hydrocolloids, 29 (2): 290297.

Khanum, H., Ramalakshmi, K., Srinivas, P. and Borse, B.B. 2011. Synergistic antioxidant action of Oregano, Ajowan and Borage extracts. Journal of Food Nutrition Science. 2: 387-392

Kykkidou, S., Giatrakou, V., Papavergou, A., Kontominas, M.G. and Savvaidis, I.N. 2009. Effect of thyme essential oil and packaging treatments on fresh Mediterranean swordfish fillets during storage at $4^{\circ} \mathrm{C}$. Food Chemistry, 115: 169-175.

Lakshmisha, I.P., Sankar, T.V., Ramalinga and Anandan, R. 2014. Biochemical studies on oxidative deterioration of lipid profile in Indian mackerel (Rastrelliger kanagurta). Trends in Biosciences, 7 (2): 115-121.

Li, T., Li, J., Hu, W. and Li, X. 2013. Quality enhancement in refrigerated red drum (Sciaenops ocellatus) fillets using chitosan coatings containing natural preservatives. Food Chemistry, 138 (2): 821-826.

Liu, A., Tegmark, M., Bowman, J., Hewitt, J. and Zaldarriaga, M. 2009. An improved method for $21-\mathrm{cm}$ foreground removal. Monthly Notices of the Royal Astronomical Society, 398 (1): 401-406.

Love, R.M. 1992. Biochemical dynamics and the quality of fresh and frozen fish. In: Fish Processing Technology. Edt. Hall, G.M. Edn.4th Chapman and Hall publishers, 1-30.

Lugemwa, F. N., Snyder, A. L. and Shaikh, K. 2013. Determination of radical scavenging activity and total phenols of wine and spices: A randomized study. Antioxidants, 2: 110-121.

Mathur, N.K. and Narang, C.K. 1990. Chitin and chitosan, versatile polysaccharides from marine animals. Journal of Chemical Education, 67: 938-942.

Mohan, C. O., Ravishankar, C. N., Lalitha, K. V. and Gopal, T. S. 2012. Effect of chitosan edible coating on the quality of double filleted Indian oil sardine (Sardinella longiceps) during chilled storage. Food Hydrocolloids, 26 (1): 167174.

Nair, R. and Chanda, S. 2005. Anticandidal activity of Punica granatum exhibited in different solvents. Pharmaceutical Biology, 43: 21-25.

Nuutila, A. M., Puupponen-Pimia, R., Aarni, M. and Oksman Caldentey, K. M. 2003. Comparision of antioxidant activities of onion and garlic extracts by inhibition of lipid peroxidation and radical scavenging activity. Food Chemistry. 81, 485-493.

Ocaño-Higuera, V. M., Maeda-Martínez, A. N., Marquez-Ríos, E., Canizales-Rodríguez, D. F., Castillo-Yanez, F. J., Ruíz-Bustos, E. and Plascencia-Jatomea, M. 2011. Freshness assessment of ray fish stored in ice by biochemical, chemical and physical methods. Food Chemistry, 125 (1): 49-54.

Olley, J. and Lovern, J.A. 1960. Phospholipids hydrolysis of cod flesh stored at various temperatures. Journal of Science and Food Agriculture, 11: 644-652.

Onsosyen, E. and O. Skaugrud, 1990. Metal recovery using chitosan. Journal of Chemical Technology and Biotechnology, 49 (4): 395-404.

Oyaizu, M. 1986. Studies on product browning reaction: antioxidant activity of products of browning reaction prepared from glucosamine. Journal of Nutrition, 44:307-315.

Ozogul, Y., Ayas, D., Yazgan, H., Ozogul, F., Boga, E. K. and Ozyurt, G. 2010. The capability of rosemary extract in preventing oxidation of fish lipid. International Journal of Food Science and Technology, 45 (8): 1717-1723

Ozyurt, G., Kuley, E., Balikçi, E., Kaçar, Ç., Gokdogan, S., Etyemez, M. and Ozogul, F. 2012. Effect of the icing with rosemary extract on the oxidative stability and biogenic amine formation in sardine (Sardinella aurita) during chilled storage. Food and Bioprocess Technology, 5 (7): 2777-2786. 
Pereira, R. N., Souza, B. W., Cerqueira, M. A., Teixeira, J. A. and Vicente, A. A. 2010. Effects of electric fields on protein unfolding and aggregation: influence on edible films formation. Biomacromolecules, 11 (11): 2912-2918.

Rac, M., and Ostric-Matijasevic, B. (1955). The properties of rosemary as an antioxidant. Rev. Fr. Corps Gras, 2, 796-803.

Reesha, K. V., Panda, S. K., Bindu, J. and Varghese, T. O. 2015. Development and characterization of an LDPE/chitosan composite antimicrobial film for chilled fish storage. International Journal of Biological Macromolecules, 79: 934-942.

Remya, S., Mohan, C. O., Bindu, J., Sivaraman, G. K., Venkateshwarlu, G. and Ravishankar, C. N. 2016. Effect of chitosan based active packaging film on the keeping quality of chilled stored barracuda fish. Journal of Food Science and Technology, 53 (1): 685-693.

Seydim, A. C. and Sarikus, G. 2007. Antimicrobial activity of whey protein based edible films incorporated with oregano, rosemary and garlic essential oils. Food Research International, 39 (5): 639-644.

Shan, B., Cai, Y. Z., Sun, M. and Corke, H. 2005. Antioxidant capacity of 26 spice extracts and characterization of their phenolic constituents. Journal of agricultural and food chemistry, 53 (20): 7749-7759.

Sherwin, E.R. 1978. Oxidation and antioxidants in fat and oil processing. Journal of American Oil Chemical Society, 55: 809814.
Sofi, F. R. 2015. Maximized Uses of Phenolic Compounds on Oxidative and Microbial Spoilage of Indian Mackerel during Different Storage Conditions (Doctoral dissertation, Karnataka Veterinary, Animal and Fisheries Sciences University, Bidar).

SPSS, I. Statistics 2010. SSS Inc., IBM Company@, Version, 20.

Tarladgis, B.G., Watts, M. and Younathan, M. 1960. A distillation method for the quantitative determination of malonaldehyde in rancid foods. Journal of Oil Chemistry Society, 37: 44-48.

Tsimidou, M., Papavergou, E. and Boskou, D. 1995. Evaluation of oregano antioxidant activity in mackerel oil. Food Research International, 28 (4): 431-433.

Vijayan, P.K. 1984. Report on training programme on retort pouch processing of fish and fish analysis at Tropical Development and Research Institute and Metal Box (R \& D), UK, Central Institute of Fisheries Technology, Cochin.

Xie, H. 2001. The mispricing of abnormal accruals. The accounting review, 76 (3): 357-373.

Yen, G. C. and Wu, J. Y. 1999. Antioxidant and radical scavenging properties of extracts from Ganoderma tsugae. Food Chemistry, 65 (3): 375-379.

Zhang, H., Wu, J. and Guo, X. 2016. Effects of antimicrobial and antioxidant activities of spice extracts on raw chicken meat quality. Food Science and Human Wellness, 5 (1): 39-48.

\section{How to cite this article:}

Kumuda, M., K. Dhanapal, K. Sravani, K. Madhavi and Praveen Kumar, G. 2018. Effect of Rosemary and Oregano Extracts Incorporated Chitosan Films on the Quality and Shelf Life of Indian Mackerel (Rastrelliger kanagurta) Steaks during Ice Storage. Int.J.Curr.Microbiol.App.Sci. 7(10): 2875-2890. doi: https://doi.org/10.20546/ijcmas.2018.710.335 